\title{
Polymorphous Light Eruption
}

National Cancer Institute

\section{Source}

National Cancer Institute. Polymorphous Light Eruption. NCI Thesaurus. Code C112201.

A red, edematous rash that occurs on areas of the skin with recent exposure to sunlight. 